\title{
Plaučių uždegimo komplikacijos
}

\author{
Arvydas Valavičius \\ Klaipèdos universitetiné ligoninè
}

Reikšminiai žodžiai: plaučių uždegimas, komplikacijos, plaučių abscesas, pleuros empiema, mirtingumas.

Santrauka. Visuomenėje igytas plaučių uždegimas - viena iš dažniausių mirties priežasčių šiuolaikiniame pasaulyje. Sukūrus antibiotikus, mirtingumas itin smarkiai sumažèjo, bet visgi tebèra 8-15 proc. bendrosios terapijos skyriuose ir iki 30 proc. intensyviosios terapijos padaliniuose.

Kiekvieną kartą diagnozuojant ir gydant plaučiu uždegimą iš karto reikia įvertinti galimus blogos prognozès veiksnius, kurie gali pabloginti ar komplikuoti plaučių uždegimo baigtį:

- amžius - daugiau 65 metų;

- gretutinès ligos, kaip antai: cukrinis diabetas, inkstų nepakankamumas, širdies nepakankamumas, lètinès plaučių ligos, alkoholizmas, imunosupresijos būklè, vèžys;

- gydymas ar gyvenimas slaugos/globos itstaigose pastaruoju laikotarpiu;

- gyvybiniai požymiai, rodantys sunkią ligos eigą: kvėpavimo dažnis > $30 \mathrm{k} . / \mathrm{min}$., sistolinis kraujospūdis $<90 \mathrm{~mm} \mathrm{Hg}$, diastolinis kraujospūdis < $60 \mathrm{~mm} \mathrm{Hg}$, kūno temperatūra $>38,3^{\circ} \mathrm{C}$;

- aptemusi sąmoné ar kitos infekcijos požymiai;

- blogi kraujo rodikliai: leukocituc mažiau kaip 4 tūkst. ar daugiau kaip 30 tūkst./mm, arterinio kraujo įsotinimas deguonimi - mažiau kaip $60 \mathrm{~mm} \mathrm{Hg}$, inkstų nepakankamumas, hematokritas - mažiau kaip 30 proc.;

- daugiaskiltis pažeidimas plaučiuc rentgenogramoje;

- bakteremija: S. pneumoniae, Legionella spp., gramneigiama infekcija ar Staph. aureus.

Reikia nepamiršti, kad ir streptokokas gali būti atsparus antibakteriniam gydymui. Tokių streptokoku paplitimas didèja nuo 1990 metuc. Kai kurių studijų duomenimis, penicilinui ir makrolidams atsparių padermių paplitimas yra atitinkamai $18-20$ proc. ir 24-36 proc.

Galimas atsparumas itariamas, kai:

- amžius - daugiau kaip 65 metų;

- anksčiau taikytas antibakterinis gydymas cefalosporinais ar makrolidais;

- ankstesnis ilgalaikis lètinių ligu gydymas chinolonais;

- alkoholizmas;

- imunosupresijos būklès (ilgalaikis gydymas gliukokortikoidais);

- daug gretutinių ligų;

- buvimas slaugos ar palaikomojo gydymo îstaigose.

\section{GALIMOS PNEUMONIJOS KOMPLIKACIJOS}

Üminis didesnio ar mažesnio laipsnio kvėpavimo nepakankamumas pasireiškia daugumai plaučių uždegimu sergančių ligonių, kai plaučiai dèl uždegimo pažeistos parenchimos negali normaliai aprūpinti deguonimi kraujo ir kartu viso organizmo. Pagrindinis simptomas - ịvairios kilmès dusulys, staiga naujai atsiradęs arba labai pasunkejjęs ankstesnis. Apklausiant ligonį, ìvertinamas fizinio krūvio toleravimas, galima pagal Niujorko širdies asociacijos skalę. Dusulys ramybeje ir apsitarnaujant rodo sunkų kvėpavimo nepakankamumą, o po stipraus fizinio krūvio - lengvą kvépavimo funkcinį nepakankamumą. Naudingas ir 6 min. ejjimo mèginys, kuri atliekant pakartotinai galima objektyviai stebėti kvejpavimo funkcijos dinamiką. Kartu būna ir kitų klinikinių požymių: padažnèjęs alsavimas, tankesnè širdies veikla, arterinè hipertenzija arba hipotenzija. Sunkaus laipsnio kvėpavimo nepakankamumo atvejais sutrinka kalba, pakinta sąmonè, sumažeja $\mathrm{SpO}_{2}$ kvėpuojant kambario oru - nesiekia 90 proc., priverstinè sédima padètis. Laboratoriškai ịvertinama tiriant arterinio kraujo dujas. Kvėpavimo nepakankamumas būna, kai:

- $\mathrm{paO}_{2}<60 \mathrm{~mm} \mathrm{Hg}$;

- $\mathrm{paCO}_{2}>50 \mathrm{~mm} \mathrm{Hg}$;

- $\mathrm{pH}<7,3$.

Ivertinus kvėpavimo funkcijos būklę, sprendžiama dèl gydymo taktikos. Niekada nepakenkia deguonies tiekimas pro nosies kateteri. Deguonies reikia tiek, kad $\mathrm{SpO}_{2}$ pasiektų daugiau kaip 90 proc. arba $\mathrm{PaO}_{2}$ arteriniame kraujyje būtuc daugiau kaip $60 \mathrm{~mm} \mathrm{Hg}$.

Jeigu gydymas deguonimi pro nosies kateteri neveiksmingas ir kvėpavimo nepakankamumas progresuoja (stiprèja dusulys, kvėpavimo dažnis $>30 \mathrm{k}$./min., hipotenzija) sprendžiama dèl papildomos ventiliacijos neinvaziniais kvépavimo aparatais arba dirbtine plaučiu ventiliacija.

Lengvejjantis kvėpavimo funkcijos nepakankamumas tai sveikimo požymis.

\section{LĖTINĖS INFEKCINĖS APATINIŲ KVĖPAVIMO TAKŲ LIGOS}

Plaučių abscesas, bronchektazès, empiema yra vienos dažniausių plaučių uždegimo komplikacijų. Jos turi ịtakos tolesniam ligonio likimui: gali lemti mirtị ar neigalumą, ilgalaiki gydymą bei dideles išlaidas. 


\section{Plaučių abscesas}

Plaučiu abscesas dažniausiai susiformuoja dèl pūlingo burnos turinio aspiracijos arba nekrozinès pneumonijos. Kliniškai pasireiškia krūtinės skausmu, karščiavimu, kosuliu, dusuliu, svorio mažejimu, gausiais pūlingais skrepliais, dvoku iš kvèpavimo takų. Tačiau neretai pasitaiko, kad ligoniai, dažniau priklausomi nuo alkoholio ar narkotikų, psichikos ligoniai, jokių kitú požymių nenurodo, iki pradeda smarkiau pūlingai skrepliuoti ar justi dvoką. Jie dèl žalingu ípročiuc ar ligos nepastebi pradinių pneumonijos požymių (karščiavimo, krūtinès skausmo ir kt.) ir atvyksta pas gydytoją jau esant griuvimo stadijai. Tai kartais ir suklaidina per pirminę apžiūrą: ligonis abscesui būdingais simptomais nesiskundžia, o pirminès apžiūros metu kai kurių reiškinių galima ir nepastebėti, juolab, kad abscesą patvirtina tik rentgeninis tyrimas. Tiriant ligoni reikia atlikti šiuos tyrimus:

- Tiesinę ir šoninę krūtinès rentgenogramas proceso dydžiui ir lokalizacijai ịvertinti.

- Krūtinès ląstos kompiuterinę tomografiją nustatyti pakitimų dydžiui, aplinkinès pneumoninès infiltracijos dydžiui bei galimai kitų rentgeninių pakitimų priežasčiai (stemplès angos išvaržai, žarnų repozicijai ị krūtinès ląstą, pneumatoraksui su skysčiu, onkologiniam procesui).

- Fibrobronchoskopiją ịvertinti galimai kliūčiai bronchų sistemoje, lèmusiai hipoventiliaciją (onkologiniam procesui, svetimkūniui, aspiracijai, bronchų deformacijai) bei paimti mikrobiologinius mėginius, išplovas rūgščiai atsparioms bakterijoms (TBC) ieškoti. Atliekant fibrobronchoskopijos procedūrą kartais pavyksta abscesą atverti, tada pūlingas sekretas pasišalina savaime.

- Skrepliu mikrobiologinius tyrimus ir tyrimus dèl RAB (rūgščiai atsparios bakterijos).

Bronchų išskyrose randama ịvairių bakterijų: aerobinių nuo 30 iki 60 proc. atvejų, Kaeistabet anaerobinių - apie 20 proc. atvejų, kai nèra imunosupresijos, ir retai - jai esant. Gali būti, kad tai priklauso nuo bronchų išskyrų èmimo technikos: bakterijos žūva susilietusios su oru. Aišku, randamas bakterijų kokteilis. Imunosupresinès būklès ligoniams dažniausiai nustatoma $P$. aeruginosa, Hemophillus spp., $X$. maltophia, H. influenza, Enterobacter spp. K. oxytoca, Legionella spp., M. avium ir Candida spp. Vartojantiems daug gliukokortikoidų išskirta Nocardia asteroides ir Cryptococcus noeoformans.

Gydymo pagrindas - antibakteriniai preparatai pagal numatomą sukèlèją. Svarbu kokiu nors būdu sukelti savaimini pūlingo skreto pasišalinimą iš pūlinio. Tam daromos posturalinio drenažo procedūros, kartotinès bronchoskopijos. Jeigu absceso padètis leidžia, atliekamas absceso transkutaninis drenavimas. Chirurginiu būdu abscesai gydomi retai, nes operuojant pūline infekcija galima užkrèsti visą krūtinès ląstos ertmę, tada baigtis gali būti bloga. Operuojama, kai būna stiprus kraujavimas, nesustabdomas konservatyviomis priemonèmis, arba pūlinys didelis ir nebelikę plaučio šiuo atveju šalinama didesnè dalis ar visas plautis.

Mirtingumas - apie 20 proc. Mirtingumą didina šie veiksniai:

- gretutinis platus uždegimas;

- anemija (mažiau kaip $10 \mathrm{~g} / \mathrm{dl}$ );

- P. aeruginosa, S. aureus, K. pneumoniae infekcija;

- absceso dydis turi reikšmès, bet ji statistiškai nereikšminga.

\section{Parapneumoninis skystis pleuros ertmèje}

Ivairus kiekis skysčio gan dažnai komplikuoja plaučių uždegimą. Susidarius palankioms sąlygoms, plaučių uždegimą sukèlę mikroorganizmai patenka ì periferines alveoles, uždegimo procesas apima ir pleuros lapelius. Dèl padidejjusio jų laidumo uždegimo skystis pradeda skverbtis i pleuros ertmę ir, netaikant adekvataus gydymo, skysčio daugeja. Didesnis nei 7,2 skysčio pH dirgina pleuros lapeliuose esančias nervų galūnes, ir ligoniui prasideda stiprūs skausmai pažeistoje vietoje. Procesui užsitęsus, skysčio padaugejja tiek, kad trukdo ligonio plaučiui normaliai kvẻpuoti, ir kvèpavimo nepakankamumas dar labiau sunkèja. Dèl uždegimo užsikemša kraujagyslès, dèl to sutrinka skysčio pasišalinimas iš pleuros ertmès. Jei skystis nepašalinamas ar negydoma, jis užsikrečia, ir prasideda pleuros ertmés empiema, empieminio skysčio pH nesiekia 7,2.

Kliniškai pasireiškia stipriu skausmu krūtineje, sustiprejjančiu îkvepiant. Tačiau, skysčio kiekiui didejjant, gan dažnai skausmas aprimsta, ir galima klaidingai nuspręsti, kad ligonio būklè pagerejjo, juolab, kad dèl to ir auskultuojant nebegirdèti uždegimo požymių. Alsavimas būna susilpnèjęs. Diagnozė labai lengvai ir greitai patikslinama atlikus pleuros ertmės ultragarsini tyrimą. Jo specifiškumas prilyginamas kompiuterinès tomografijos. Aišku, jei yra galimybė, reikia atlikti krūtinès kompiuterinę tomografiją. Patikslinama skysčio kiekis, lokalizacija, uždegimo apimtis bei galimos kitos skysčio pleuros ertmèje priežastys. Skysčio kilmei ir pobūdžiui patikslinti atliekama pleuros ertmès diagnostinè gydomoji punkcija. Jeigu randama pūlingo skysčio ar pH yra mažesnis nei 7,2, atliekama skubi pleuros ertmės drenažo procedūra. Paprastai tinkamai gydant, klinikinis pagerèjimas pastebimas per savaitę.

\section{Pleuros ertmès empiema}

Pleuros empiema - šiuc dienų pulmonologijos problema. Nepaisant šiuolaikinio antibakterinio gydymo galimybių, empiemos atvejų nuo 1990 metų daugèja. JAV ir Jungtinèje Karalystèje kasmet ji diagnozuojama apie 65 tūkst. ligonių, iš kurių 15 proc. miršta, o 30 proc. reikia chirurginès pagalbos.

Empiemą dažniausiai sukelia kompleksas bakterijų. Reikia pabrèžti, kad apie 40 proc. atvejų priežastinis sukèlejjas nenustatomas. Sukèlèjai linkę keistis. Pastarųjų metu tyrimuose bandyta nustatyti naujus sukèlejjus. 2005 metais 52 Jungtinèje Karalystèje centruose ištyrus ligonius, sergančius pleuros empiema, 32 proc. rasta Streptococcus millerii, 13 proc. - S. pneumoniae, 11 proc. - S. aureus ir 10 proc. - enterobakteriju (lentelè), daugiausiai ligoniams, sergantiems cukriniu diabetu ar onkologinèmis ligomis. Taivane dažniau rasta gramneigiamų bakterijų, o Ispanijoje S. aureus.

Pastebèta, kad empiemų daugèja jauniems ligoniams (18-50 m.): nuo 7,6 proc. $1996-2001 \mathrm{~m}$. iki 14,9 proc. 2005-2011 m. Manoma, kad tai lèmé 3,19a ir 1 serotipo pneumokoku plitimas: jų randama iki 40 proc. pneumokokinès empiemos atvejų. Jaunesniems ligoniams labiau tikètina pneumokokinès kilmès empiema, o vyresniems ir sergantiems sunkiomis gretutinèmis ligomis - S. aureus ir gramneigiamų bakterijų. Mirtingumas šioje grupeje netgi JAV yra didelis - iki 20 proc. atvejų. Kodèl keičiasi 
Lentelè. Empiemos atveju randami mikroorganizmai

\begin{tabular}{l|c}
\hline Mikroorganizmai & Dažnumas (proc.) \\
\hline Strep. millerii grupe & 32 \\
Strep. pneumoniae & 13 \\
Kiti streptokokai & 7 \\
S. aureus & 11 \\
Anaerobai & 16 \\
Enterobacter & 7 \\
Proteus & 3 \\
Haemophilus influenzae & 3 \\
Kiti & 8 \\
\hline
\end{tabular}

sukèlejjai, nėra visiškai aišku. Manoma, kad minètų serotipu pneumokokai yra atsparūs fagocitozei, aktyviau skverbiasi ị audinius, greičiau pasiekia pleuros ertmę ir ją užkrečia.

Gydymo pagrindas - skubus pleuros ertmès drenažas kuo didesniam kiekiui pūlių pašalinti ir antibakteriniai vaistai. Skirtini 2 ar 3 klasès cefalosporinai, derinami su anaerobiniu preparatu, klindamicinas, adekvatus skysčiu kiekis, papildoma deguonies terapija, baltymu pusiausvyros palaikymas.

Priklausomai nuo ligonio bendrosios būklès, gretutinių ligų, gydymas gali užtrukti nuo savaičių iki mènesių arba net pereiti ị lètinę būklę.

Profilaktika - šiuolaikinès pneumokokinès vakcinos gali sutrukdyti patogenu invaziją ir kolonizaciją kvejpavimo takuose, tuo pačiu sumažinti galimybę susirgti pneumokokiniu plaučių uždegimu ir pleuros empiema.

\section{MIRTINGUMAS}

Nepaisant naujausių medicinos laimèjimų, mirtingumas nuo plaučių uždegimo tebèra didelis netgi ekonomiškai stipriose šalyse - nuo 9 iki 11 procentų. Tyrimais bandoma nustatyti galimas mirties priežastis bei skatinančius veiksnius. Antai, Kanadoje atliktame tyrime tirti 3042 plaučių uždegimu sergantys ligoniai, gydyti stacionaro sąlygomis; iš jų mirè 246 (8,1 proc.). Vertinta sunkumo laipsnis, funkcinè būklè, konsultacijos, med. seserų darbas, konsultantai ir ankstyvasis bei vèlyvasis mirtingumas. Ligonių amžiaus vidurkis - $69 \pm 17$ metuc, vyrų buvo 52,5 proc., slaugos ar globos įstaigu gyventojų - 31 proc., 62 proc. judejo patys, 7,2 proc. reikejjo vežti vežimèliu, 3,4 proc. buvo lovos režimo, dèl blogèjančios būklès ì RITS perkelti 5,4 proc. ligonių.

Nustatyta, kad labai reikšmingas mirtingumo veiksnys galimybė judèti. Iš ligonių, kuriuos reikejjo vežti vežimèliu, mirè net 20,1 proc., buvusių priverstinai gulimos padèties 25,2 proc., o laisvai judančių mirtingumas buvo 4,0 proc., ir amžiumi jie buvo vyresni (73 ir $74 \mathrm{~m}$.).

Gydymas taip pat turèjo įtakos. Gydytų vien tik levofloksacinu bei cefuroksimo ir azitromicino deriniu mirtingumas buvo atitinkamai 5,3 ir 5,4 proc., o kitais antibiotikais gydytuc ligoniu grupejje mirè 12,2 proc.

Stebetina, bet, lyginant su kitais tyrimais, pirmos antibiotikų dozès skyrimo laikas ligoniui patekus ị prièmimo skyrių neturejo įtakos mirtingumui. Grupeje ligonių, kuriems gydymas pradètas nuo 0 iki 4 val., mirè 9,2 proc., tarp 4 ir 8 val. 8,6 proc., o po daugiau kaip 8 val. $-8,7$ proc.
Ligonio bendroji būklè, amžius, konsultantų reikalingumas, gydymo vieta veikè ir ankstyvąji, ir vèlyvąji (> 5 dienų) mirtingumą. Pneumonijos gydymo algoritmų laikymasis sumažina ankstyvąji mirtingumą, bet neturi itakos vèlyvajam.

Mažas limfocitu ir didelis kalio kiekis padidina ankstyvąji mirtingumą, o vėlyvojo neveikia. 65 proc. mirusiųjų per pirmąsias penkias dienas nustatyta limfocitopenija, palyginti su 29 proc. išgyvenusiųjų. Kol kas negalima paaiškinti šio reiškinio priežasties, gali būti, kad tai susiję su maitinimusi. Atkreipiamas dèmesys, kad ŽIV mirtingumui ittakos neturèjo: nè vienas iš 25 ŽIV užsikrètusių ligonių nuo pneumonijos nemirè. Hiperkalemija, galimas slapto inkstų nepakankamumo žymuo, irgi gali būti mirties rizikos veiksnys.

Kiti tyrèjai atkreipia dèmesi, kad ir sumažèjęs, ir padidejęs gliukozès kiekis taip pat gali prognozuoti didesnị mirtingumą. Tiriama ir vit. D kiekio ịtaka paveikti plaučių uždegimo baigtị.

Tuo tarpu antibiotiku pasirinkimas turi įtakos vèlyvajam mirtingumui ir neturi ankstyvajam.

Didelę reikšmę turi gydymo vieta. Nurodoma, kad gydymo ịstaigoje nepakankamas slaugytojų skaičius ar nepakankama jų kvalifikacija padidina mirtingumą, ir atvirkščiai gydymas skyriuose, kuriuose dirba patyrę gydytojai ir slaugos personalas, mirtingumą sumažina. Kriterijumi buvo pasirinktas ligonių, gydytų toje ịstaigoje nuo plaučių uždegimo, skaičius: kuo jis didesnis, tuo mirtingumas mažesnis.

Specialistų konsultacijos poreikis buvo susijęs su didesniu mirtingumu, nes specialistai kviečiami būtent tada, kai ligos eiga komplikuota ir sunki dèl ịvairių priežasčių.

Taigi plaučiu uždegimas - gana sunki problema gydytojo praktikoje ir, nepaisant antibakterinio gydymo pasiekimų, komplikuojasi gyvybei pavojingomis būklèmis, lemiančiomis dideli mirtingumą.

\section{COMPLICATION OF PNEUMONIA}

ARVYDAS VALAVICIUS

DEPARTMENT OF PULMONOLOGY KLAIPEDDA UNIVERSITY HOSPITAL

Keywords: pneumonia, lung abscss, empiema pleurae, mortality. Summary. This article about complication of pneumonia and factors influacing in mortality.

\section{LITERATŨRA}

1. Joaquin Burgos et al. The Increasing Incidenc of Empiema Curr Opin Pulm Med. 2013; 19(4): 350-356.

2. Naresh G. Mansharamani et al. Curr Opin Pulm Med 2003; 9.

3. Thomas J Marrie et al. Factor Influencing In-Hospital Mortality in Community-Aquired pneumonija. CHEST 2005; 127: 1260-1270.

4. Jeffrey Rubins et al. Pleural Effusion Treatment and Management, 2012 Mdscape referens.

5. Emma Hitt Vitamin D levels Linked to Mortality in Patient With Pneumonia Respirotology 2011; 16: 611-616.

6. Deborah F. Low Levels of Hospital Nurses Linked To Patient Deaths. N Engl J Med 2002; 346(22); 1715-1722. 